\title{
Aplikasi Game Cerita Rakyat Bali Sebagai Sarana Pendidikan Karakter Anak Berbasis Mobile
}

\author{
I Dewa Gede Agung Pandawana ${ }^{1}$, Dewa Putu Yudhi Ardiana $^{2}$ \\ Program Studi Teknik Informatika, STMIK STIKOM Indonesia \\ JL. Tukad Pakerisan 97 Denpasar, Bali \\ 1vandawaa@yahoo.com \\ 22dewayudhi@stiki-indonesia.ac.id
}

\begin{abstract}
Abstrak
Cerita rakyat mempunyai nilai kearifan lokal yang dapat digunakan dalam pembelajaran karakter pada anak. Penyampaian cerita rakyat kepada anak lebih banyak dilakukan orang tua dengan bercerita. Fenomena kurang diminati cerita rakyat oleh anak salah satunya disebabkan oleh kurangnya waktu orang tua untuk menyampaikan cerita. Penelitian ini bertujuan mentransformasikan cerita rakyat bali kedalam aplikasi game berbasis mobile sehingga lebih menarik dan dapat digunakan sebagai sarana mengajarkan pendidikan karakter yang didapat dari nilai kearifan lokal cerita rakyat dan memperkenalkan budaya lokal kepada anak. Pesan moral yang ingin disampikan dalam game ini adalah tepat janji, jujur dan suka menolong melalui cerita crukcuk kuning, i kekua dan i lacur. Hasil Black-box testing pada beberapa perangkat seluler dengan sistem operasi android menunjukkan funsionalitas secara umum aplikasi sudah sesuai dengan yang diharapkan. Berdasarkan penilaian menggunakan kuesioner didapat aplikasi Game Cerita Rakyat Bali dari aspek media, hiburan dan isi mempunyai kategori baik.
\end{abstract}

Kata kunci: Pendidikan Karakter, Kearifan Lokal, Cerita Rakyat, Game, Mobile.

\begin{abstract}
Folklore has a value of local wisdom that can be used in character learning for children. the delivery of folklore to children is mostly done by parents through telling stories. the phenomenon of less popular folklore by children one of them due to lack of time parents to convey the story. This study goals to transform Balinese folklore into mobile-based game applications, in order to make it more interesting, further, it could be use as a means of character education teaching gained from the local wisdom of folklore and introducing local culture to children. Moral messages that want to be presented in this game is the right promise, honest and helpful through crukcuk kuning story, $i$ kekua and $i$ lacur. The results of black-box testing on several mobile devices with Android operating system show the general functionality of the application is in accordance with the expected. Based on the assessment using questionnaires obtained the application of the Bali Folklore Game from the aspect of media, entertainment, and content has a good category.
\end{abstract}

Keywords: Characther Building, Local Wisdom, Folklore, Game, Mobile.

\section{Pendahuluan}

Salah satu karya sastra yang mempunyai nilai kearifan lokal adalah cerita rakyat. Nilai-nilai pembentukan karakter dapat digali dari kearifan-kearifan lokal yang berasal dari budaya sendiri sebagaimana yang terdapat dalam cerita rakyat [1]. Cerita rakyat dalam kaitan dengan media pendidikan karakter dapat digunakan sebagai bahan permenungan dalam konteks self education, yang mana selft education sendiri dapat dikaitkan dengan upaya seorang pribadi untuk mengolah dirinya sepanjang hayat [2].

Budaya Bali kaya akan cerita rakyat. Setiap cerita memiliki kearifan lokal nya sendiri-sendiri. Hasil penelitian Parmini tentang peran cerita rakyat bali dalam pendidikan karakter 
menunjukkan perubahan sikap positif dari anak setelah disuguhi cerita rakyat empat kali saat sebelum tidur maupun dalam kondisi santai [3]. Perubahan yang terjadi umumnya sikap anak sesuai dengan yang dicontohkan dalam cerita. Penelitian tersebut menunjukkan bagaimana cerita rakyat bali dapat memberikan nilai kearifan lokal dan pengaruh karakter positif pada anak.

Penyampaian cerita rakyat bali lebih banyak disampaikan ke anak melalui cara bercerita atau storytelling, jika dalam bahasa bali diistilahkan mesatua. Seiring perkembangan zaman, banyak tantangan yang dihadapi dalam bercerita, Rahmawati dalam penelitiannya mengemukakan tantangan yang dihadapi dalam bercerita salah satunya dari orang tua sendiri yang sibuk dan tidak punya waktu untuk bercerita. Tantangan lain yang muncul seiring perkembangan teknologi adalah daya tarik yang ditawarkan oleh televisi atau permainan yang lebih modern oleh gadget.

Penelitian yang dilakukan oleh Santoso, Sunarya dan Arieshanti di latar belakangi oleh kurang populernya cerita rakyat dibandingkan cerita dari luar indonesia, hal tersebut disebabkan karena orang tua jarang meluangkan waktu untuk menceritakan cerita rakyat kepada anak dan kurang dikemas secara menarik cerita rakyat Indonesia dibandingkan cerita luar yang didukung oleh media digital [4]. Hal senada juga disampaikan oleh Grady, Karnadi dan Hendra dalam penelitiannya juga berlatar belakang fenomena lebih senangnya anak usia sekolah terhadap cerita luar negeri dibandingkan cerita lokal [5]. Dua penelitian tersebut mempunyai latar belakang kurang populernya cerita rakyat di kalangan anak. Senada dengan dua penelitian itu, cerita rakyat Bali juga mengalami fenomena mulai kalah populer dibandingkan cerita asing dengan penyebab kurangnya waktu orang tua bercerita dan kurang menariknya pengemasan ke dalam media yang didukung teknologi.

Berdasarkan permasalahan kurang populernya cerita rakyat dikalangan anak, penelitian ini difokuskan untuk mentransformasikan cerita rakyat kedalam basis media yang saat ini populer yaitu mobile. Cerita rakyat yang digunakan dalam penelitian ini adalah cerita rakyat Bali yang mengandung nilai kearifan lokal yang baik dalam perkembangan karakter anak dan ditransformasikan kedalam bentuk game (permainan elektronik) berbasis mobile. Pemilihan bentuk game mengacu pada hasil penelitan yang berjudul Pengenalan Tradisi Budaya Bali Melalui Aplikasi Game Explore Bali Berbasis Android, dimana hasil penelitian tersebut menunjukkan peningkatan pengetahuan pengguna tentang tradisi budaya Bali setelah bermain game Explore Bali [6]. Pemilihan basis mobile karena teknologi tersebut banyak digunakan anak dan sangat pesat perkembangannya.

\section{Metodologi Penelitian}

Aplikasi Game Cerita Rakyat Bali dikembangkan menggunakan model waterfall melalui tahapan analysis, design, code dan test. Pada tahapan analysis, Data yang diperlukan terkait kebutuhan aplikasi terkait cerita rakyat bali yang mengandung pesan moral yang baik untuk karakter anak dikumpulkan melalui wawancara, observasi dan studi literatur.

Game Cerita Rakyat Bali merupakan sebuah game yang mencoba untuk mengenalkan kearifan lokal yang terdapat dalam cerita rakyat pada anak usia 6-12 tahun. Cerita Rakyat yang digunakan dalam aplikasi Game Cerita Rakyat Bali ini adalah I Kekua yang mempunyai pesan moral tepat janji, Crukcuk Kuning yang mempunyai pesan moral kejujuran dan I Lacur yang mempunyai pesan moral suka menolong.

Game akan menyuguhkan pemain dengan cerita pengantar sebelum memasuki permainan. Setiap permainan yang akan dihadapi pemain akan berbeda tergantung dari cerita masingmasing. Setelah pemain mencapai skor yang ditentukan maka pemain akan diarahkan menuju ke cerita penutup disertai dengan pesan moral yang terkandung dalam cerita tersebut. Gambar 1 menunjukkan sitemap dari aplikasi Game Cerita Rakyat Bali. 


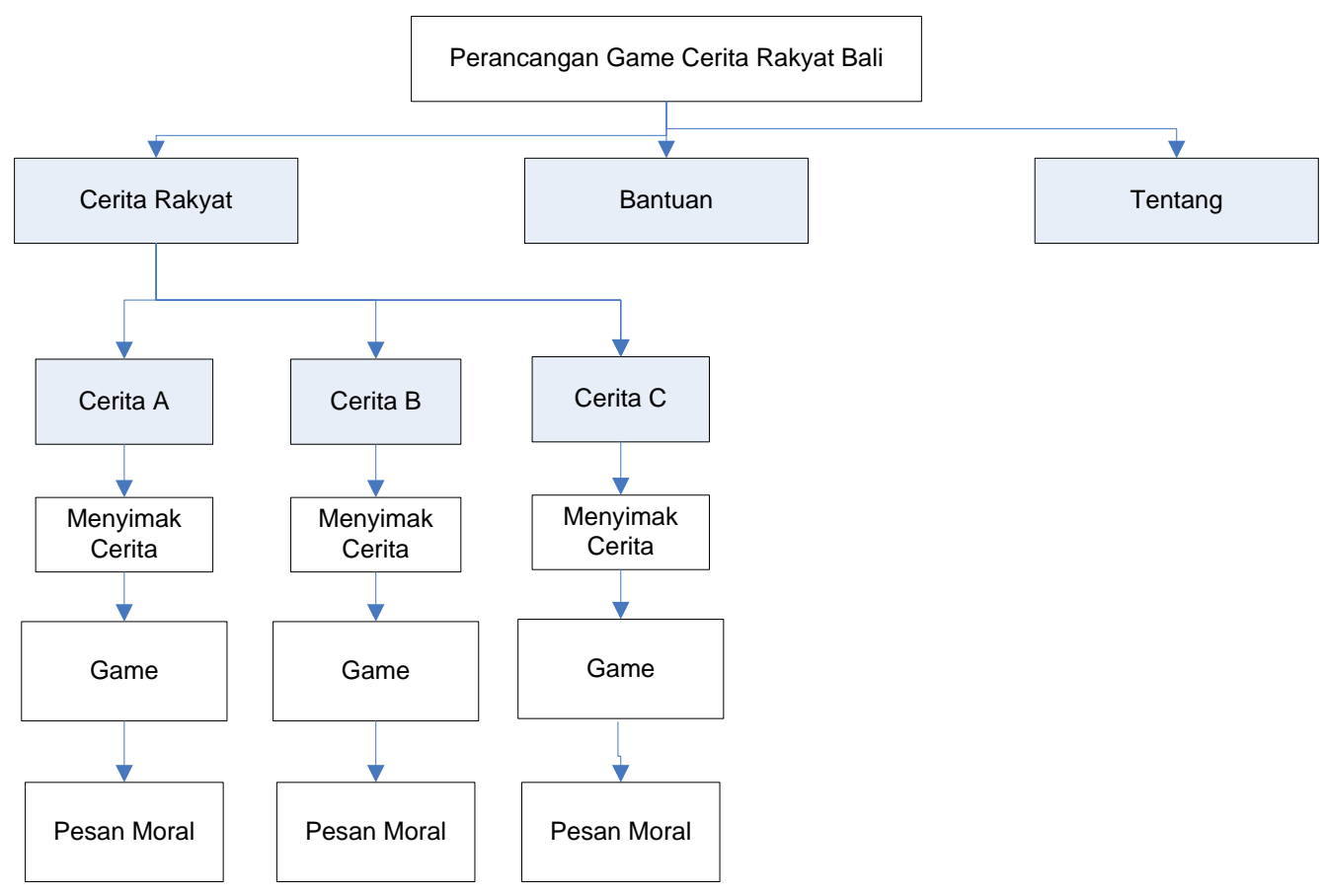

Gambar 1. Sitemap Aplikasi Game Cerita Rakyat Bali

Pada tahapan Design, hasil tahapan analysis diterjemahkan kedalam representasi perangkat lunak. Diagram Use Case pada Gambar 2 dipergunakan untuk menunjukkan fungsi yang terdapat pada aplikasi game dan interaksinya dengan pemain. Pemain memiliki fitur untuk melihat cerita dan memainkan game, terdapat juga fitur bantuan dan informasi tentang pembuat aplikasi game cerita rakyat.

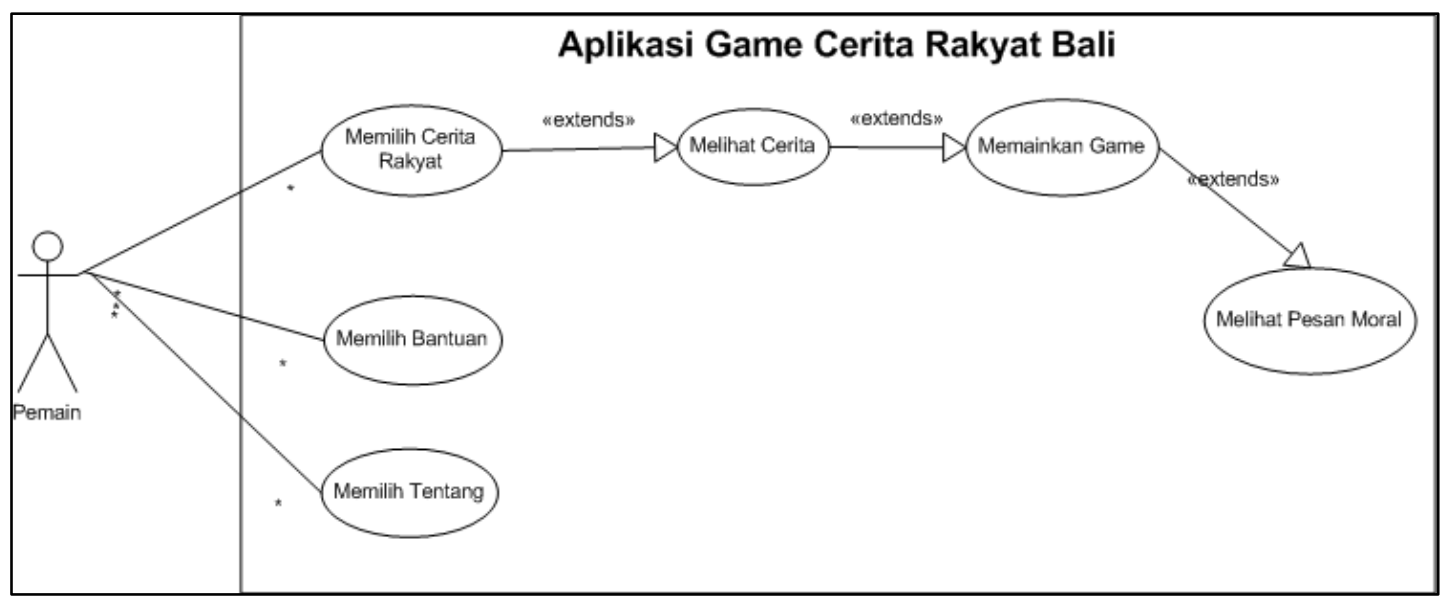

Gambar 2. Diagram Use Case dari Aplikasi Game Cerita Rakyat Bali

Pada tahapan code, hasil tahapan design diterjemahkan kedalam kode program. Hasil implementasi tergandung dari hasil tahapan design pada tahapan sebelumnya. Setelah tahapan code, selanjutnya tahapan test yang melakukan pengujian terhadap aplikasi yang sudah dibuat. Pengujian pada penelitian ini menggunakan Black-box testing pada perangkat seluler bersistem operasi android untuk menguji fungsionalitas dari aplikasi dan menggunakan kuesioner untuk melihat respon dari pengguna terhadap aplikasi yang dibuat. 


\section{Kajian Pustaka}

\subsection{Cerita Rakyat}

Cerita rakyat mengisahkan suatu kejadian di suatu tempat atau asal muasal suatu tempat. Fungsi cerita rakyat selain sebagai hiburan, juga sebagai suri tauladan terutama cerita yang mengandung pesan pendidikan moral [7].

\section{2. $\quad$ Mobile Games}

Permainan mobile adalah video game dimana pengguna menggunakan media smartphone atau PDA. Mobile Games mempunya beberapa keuntungan yaitu mudah dibawa karena mempunyai baterai yang bisa diisi ulang, mudah ditempatkan dimana saja dan kebanyakan game bersifat gratis [8].

\section{Hasil dan Pembahasan}

Cerita Rakyat Bali dapat dikembangkan kedalam aplikasi game mobile berbasiskan sistem operasi Android. Kuesioner digunakan untuk melihat antusiasme pemain dalam memainkan Game Cerita Rakyat Bali.

\subsection{Tampilan Game Cerita Rakyat Bali}

Sub bab ini membahas mengenai tampilan game Cerita Rakyat bali. Pada menu utama yang ditunjukkan Gambar 3, terdapat beberapa tombol yaitu cerita rakyat, bantuan, pengaturan, dan tentang. Pemain dapat memulai permainan dengan memilih tombol cerita rakyat.

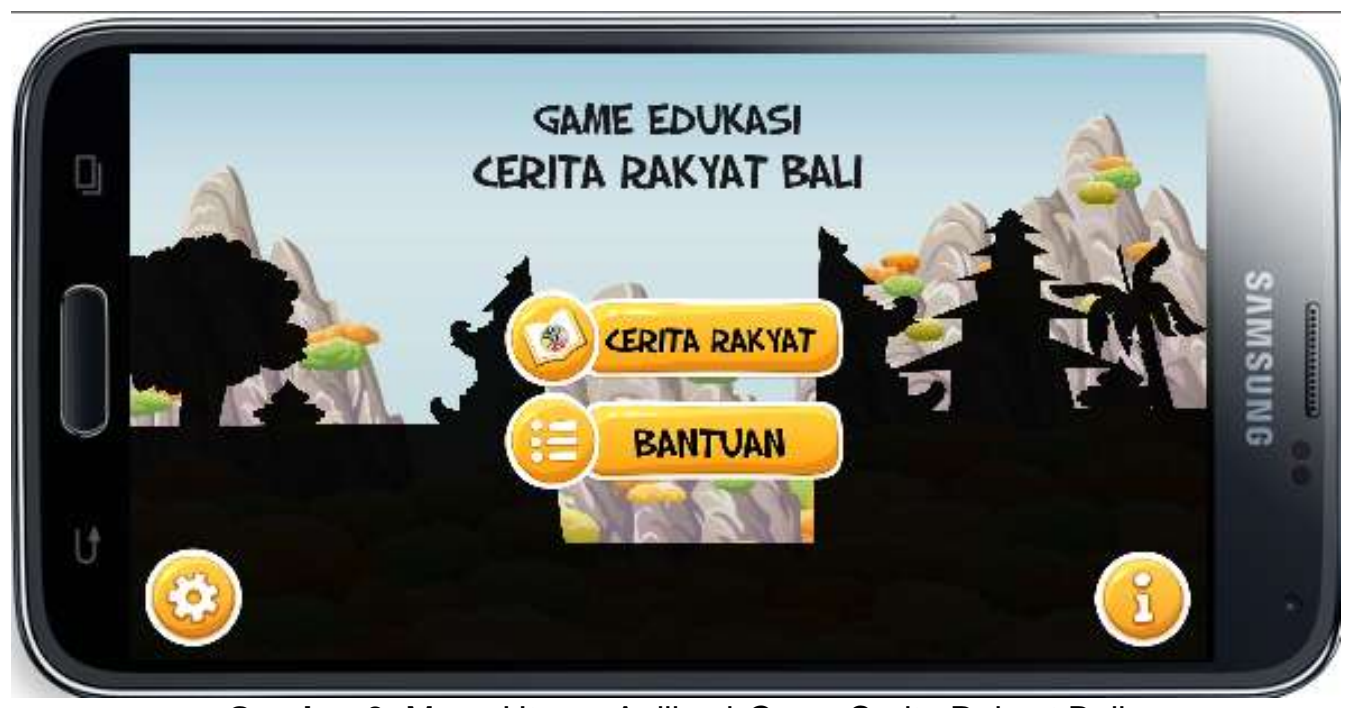

Gambar 3. Menu Utama Aplikasi Game Cerita Rakyat Bali

Bagian memillih cerita pada Gambar 4, menampilkan cerita-cerita yang terdapat pada game. Untuk menuju kesalah satu cerita, pengguna dapat menekan tombol sesuai dengan nama cerita. Terdapat tombol kembali pada pojok kiri atas untuk kembali ke tampilan menu utama. 


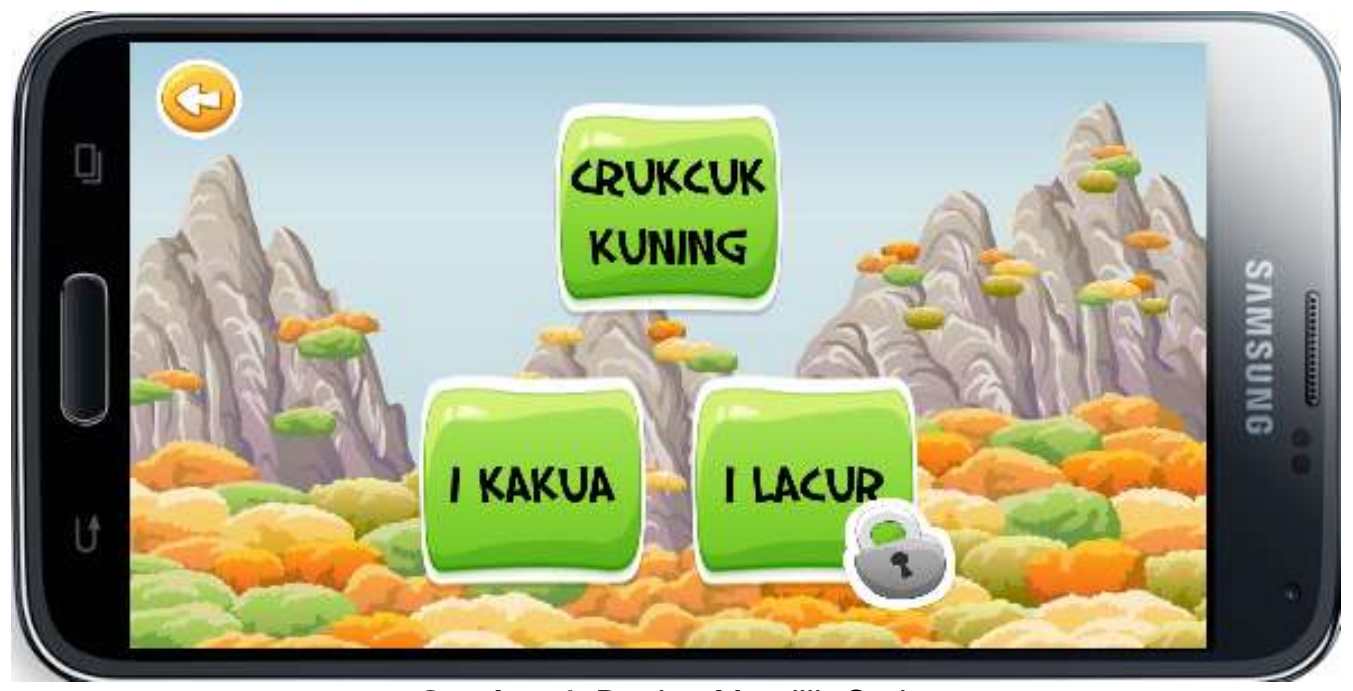

Gambar 4. Bagian Memilih Cerita

Sebelum memasuki bagian permainan, pemain akan ditampilkan bagian cerita yang ditunjukkan pada Gambar 5. Terdapat beberapa tampilan cerita yang dinarasikan dengan audio. Terdapat tombol panah kiri dan kanan untuk kembali ke tampilan cerita sebelum dan sesudahnya. Terdapat tombol pada pojok kiri atas untuk kembali ke tampilan memilih cerita.

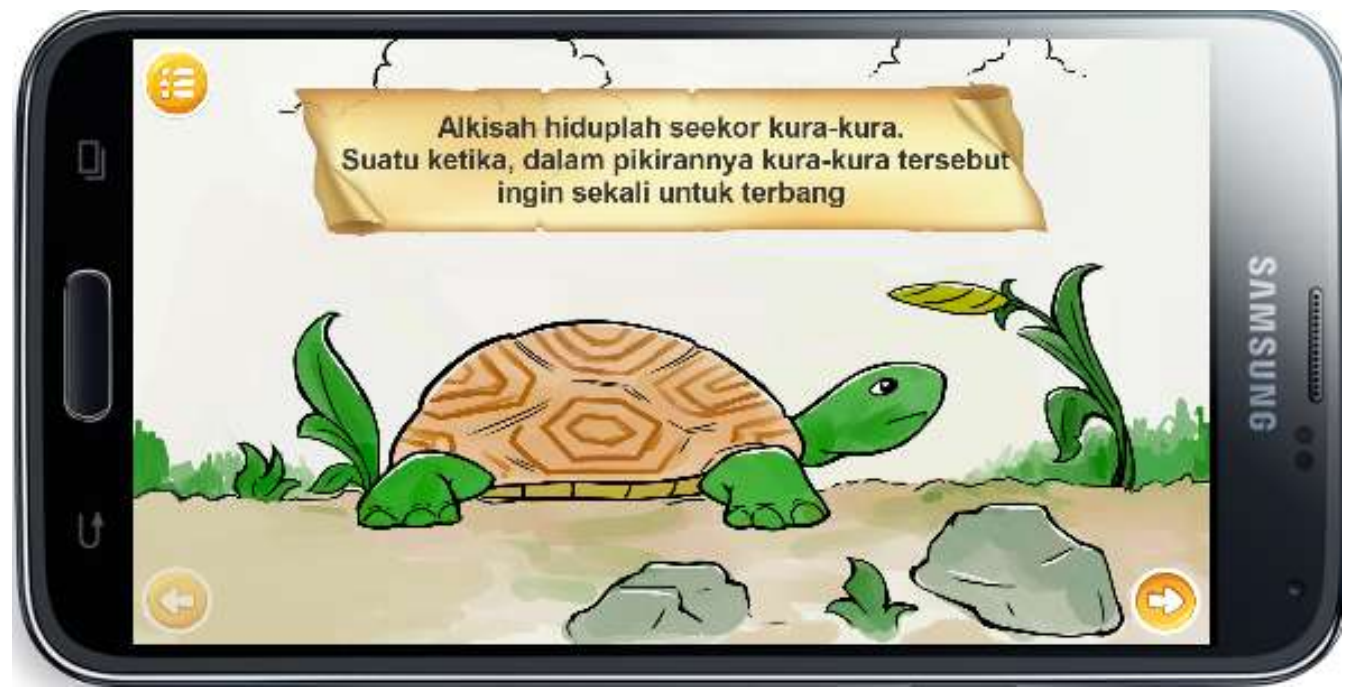

Gambar 5. Bagian Cerita

Setelah bagian cerita usai, pemain akan diarahkan menuju bagian mulai permainan yang ditunjukkan pada Gambar 6. Pada bagian ini terdapat petunjuk untuk memainkan game. Terdapat tombol main untuk memulai permainan, tombol menu dipojok kiri atas untuk kembali ke tampilan memilih cerita dan tombol kembali di kiri bawah untuk kembali ke tampilan cerita. 


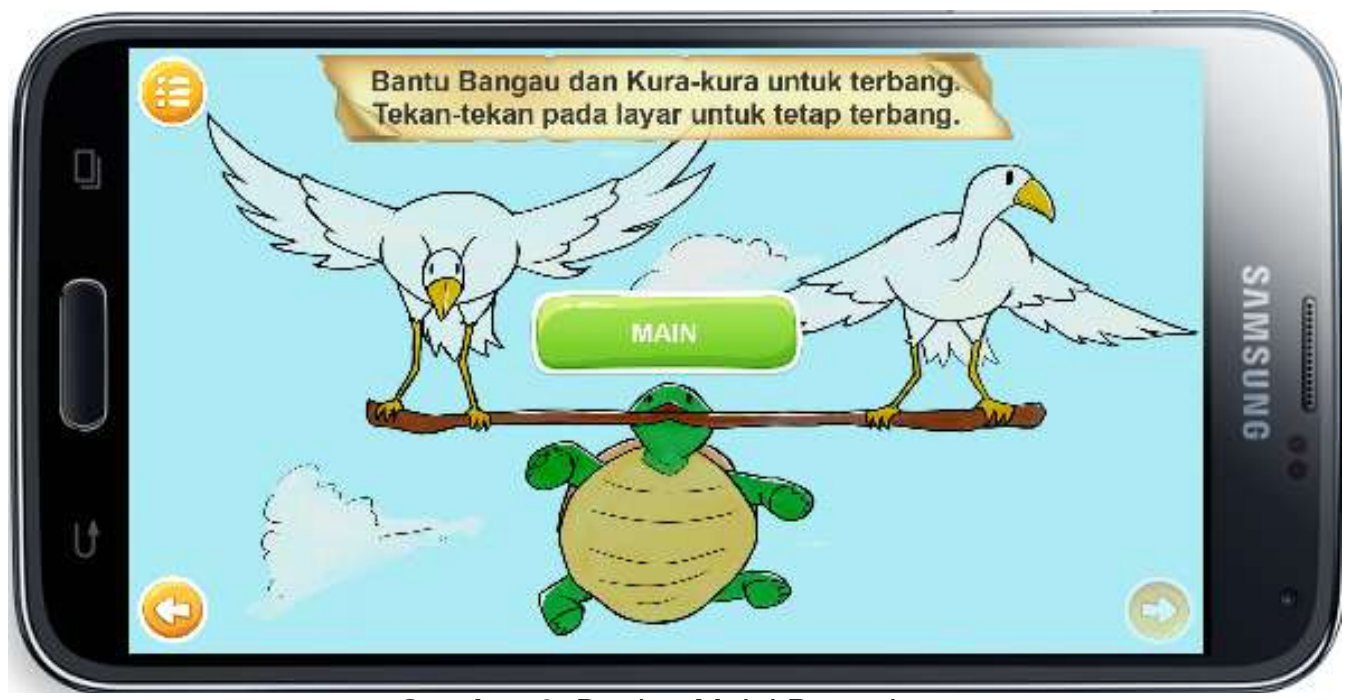

Gambar 6. Bagian Mulai Permainan

Gambar 7 adalah bagian permainan, pemain mulai memainkan permainan terkait dengan cerita yang dipilih. Setiap cerita pengguna akan mempunyai peran yang berbeda dan tugas yang berbeda. Terdapat skor batas yang jika pengguna sampai meraihnya maka pengguna dapat melanjutkan ke tahap selanjutnya. Jika tidak maka tampilan permainan akan diulang kembali.

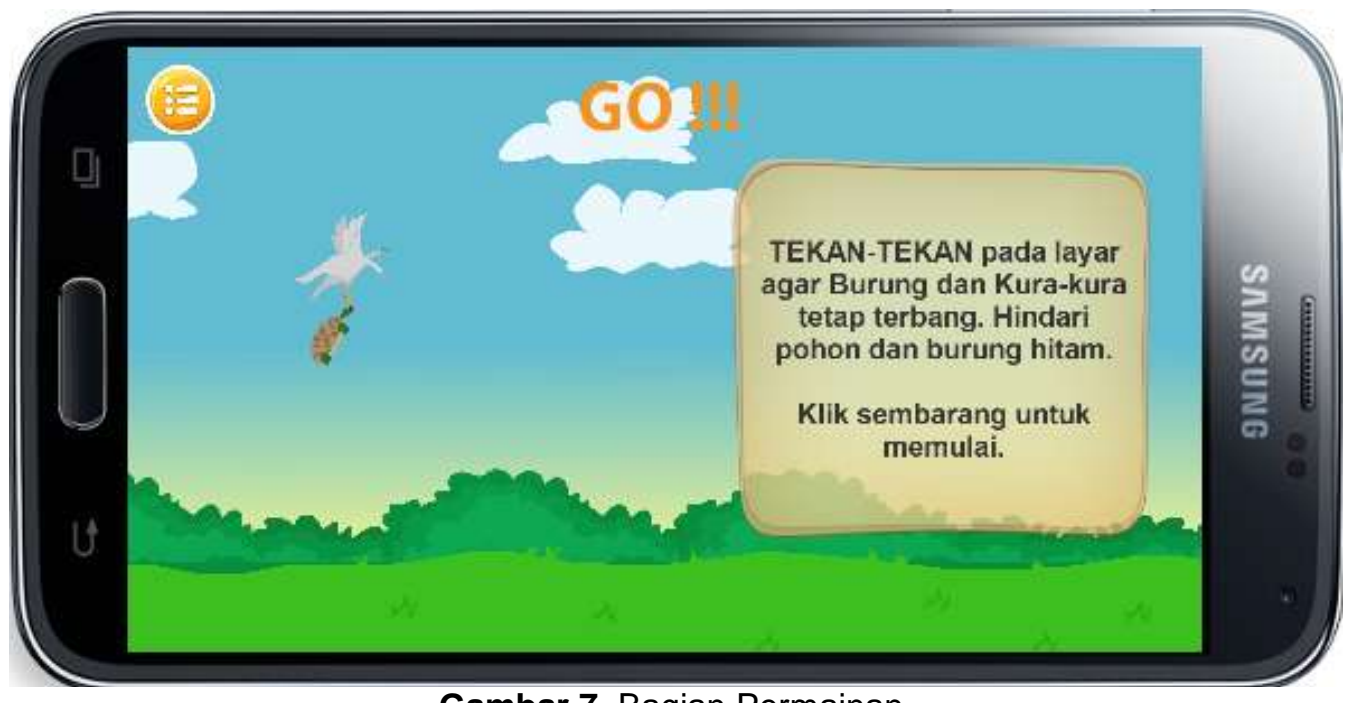

Gambar 7. Bagian Permainan.

Setelah pemain dapat mencapai skor yang telah ditentukan, akan tampil bagian hasil untuk melanjutkan ke tampilan berikutnya. Terdapat tombol untuk kembali ke tampilan memilih cerita dan tombol kembali mengulang permainan. Bagian hasil dapat dilihat pada Gambar 8. 


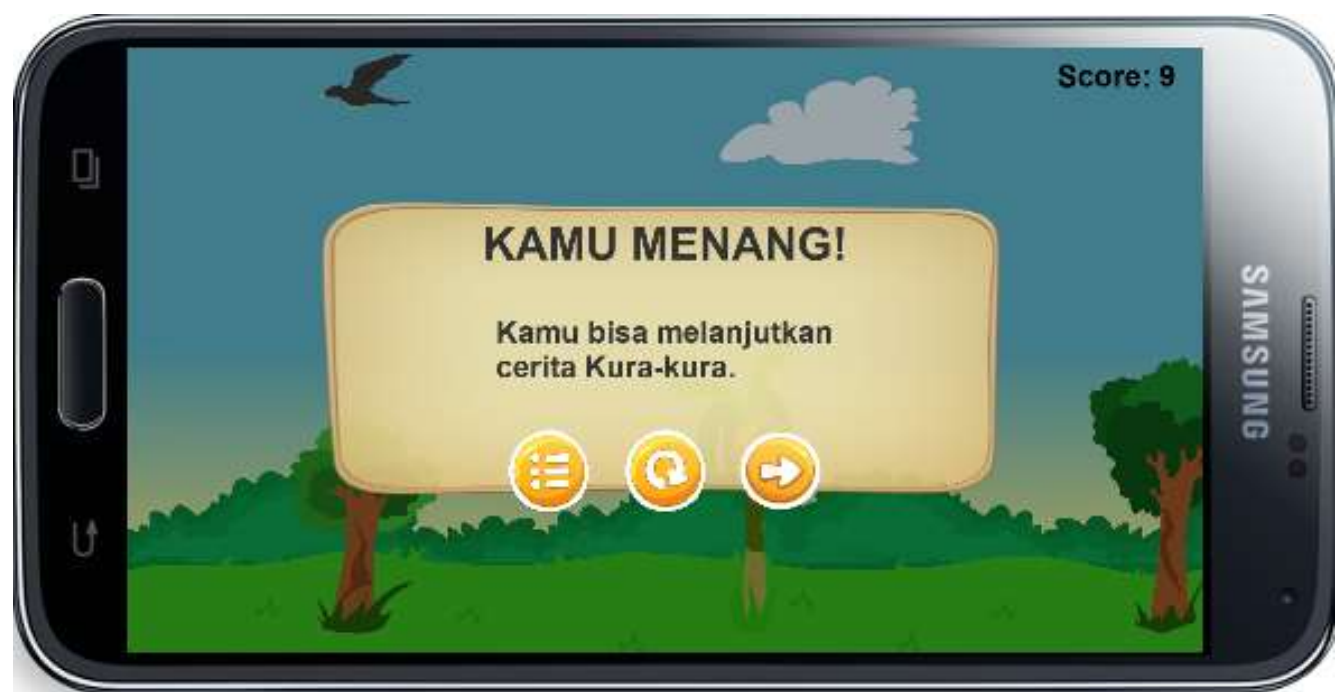

Gambar 8. Bagian Hasil.

Gambar 9 menunjukkan bagian cerita penutup yang akan muncul setelah pengguna berhasil mencapai skor tertentu dalam game. Pada tampilan ini, pengguna akan disuguhkan cerita akhir dari yang cerita yang dipilih. Tombol pada kanan bawah untuk menuju ke halaman tampilan pesan moral.

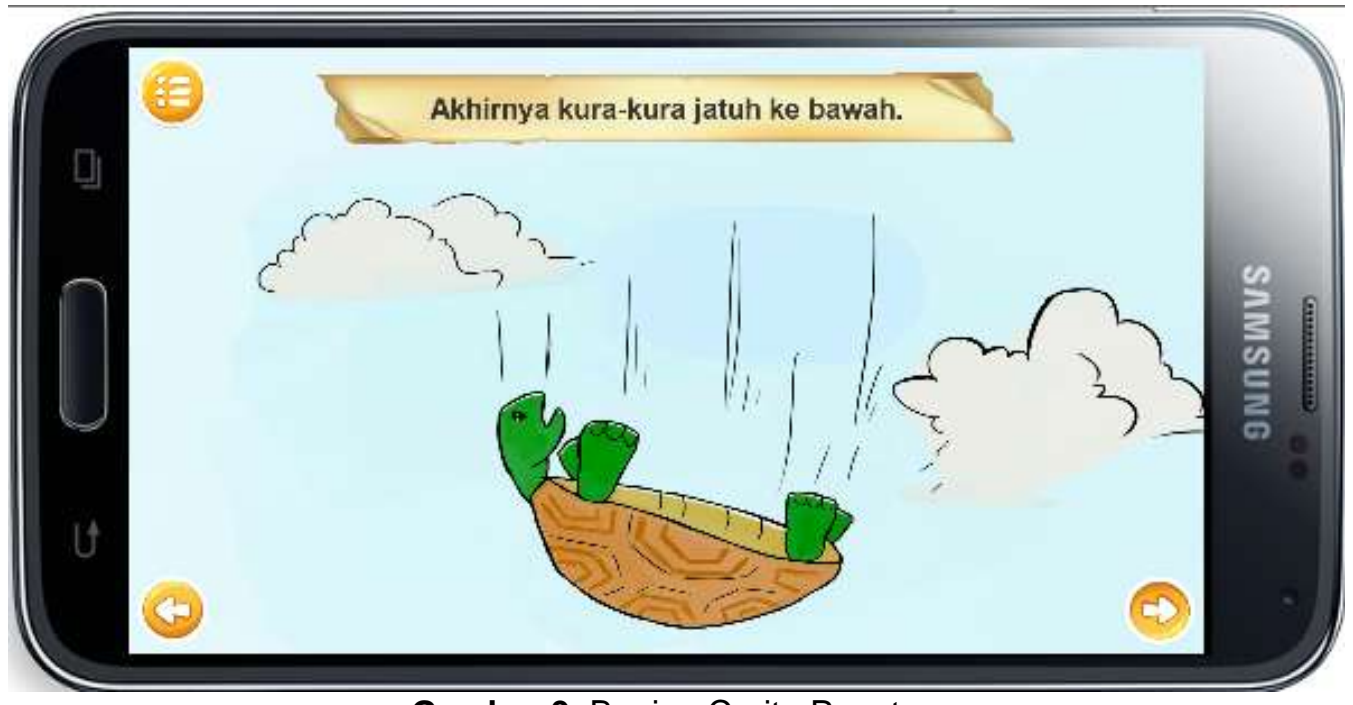

Gambar 9. Bagian Cerita Penutup

Bagian pesan moral berisi pesan moral yang terdapat pada cerita yang dipilih. Terdapat tombol kembali ke menu tampilan memilih cerita pada pojok kanan atas, tombol kembali ke tampilan cerita penutup pada tombol kiri bawah. Bagian pesan moral ditunjukkan pada Gambar 10. 


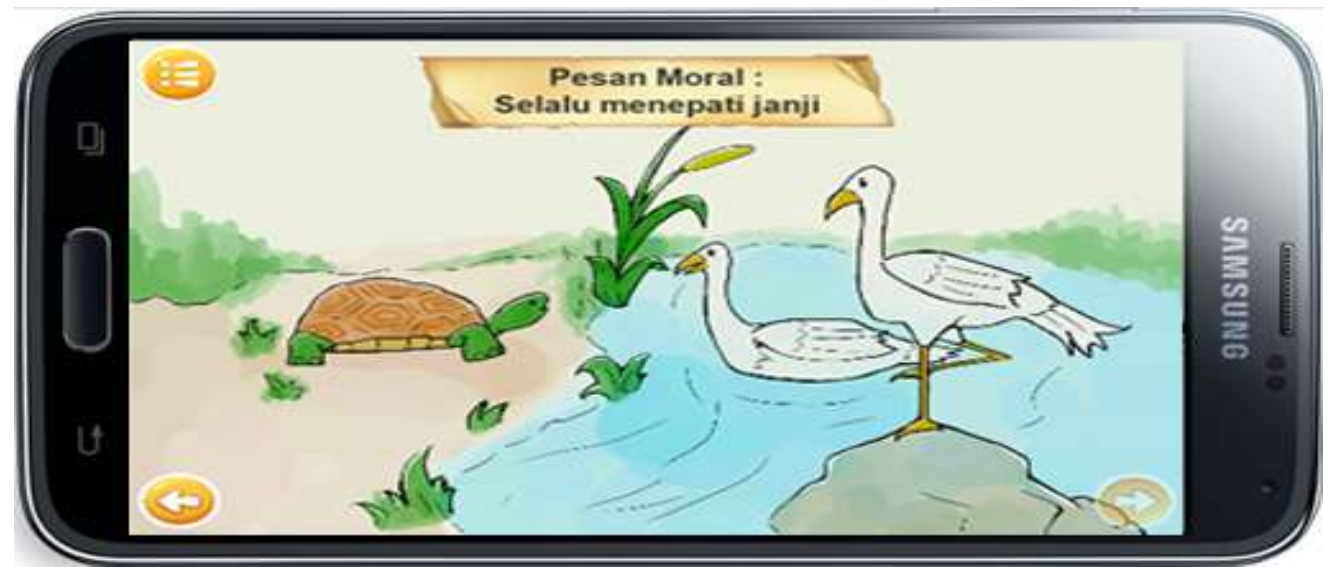

Gambar 10. Bagian Pesan Moral

Gambar 11 menunjukkan tampilan setting yang dipergunakan untuk menonaktifkan musik dan suara yang ada pada aplikasi game.

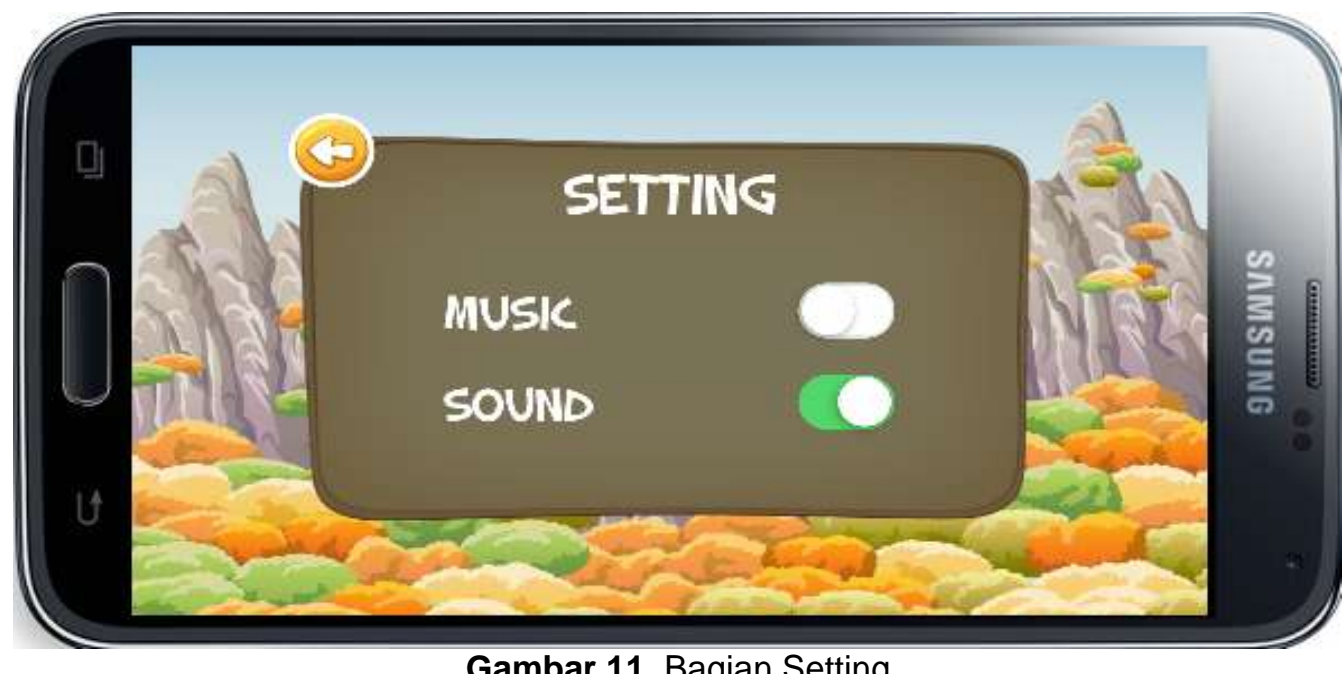

Gambar 11. Bagian Setting

Gambar 12 memperlihatkan bagian tentang yang terdapat informasi tentang pembuat dari aplikasi game.

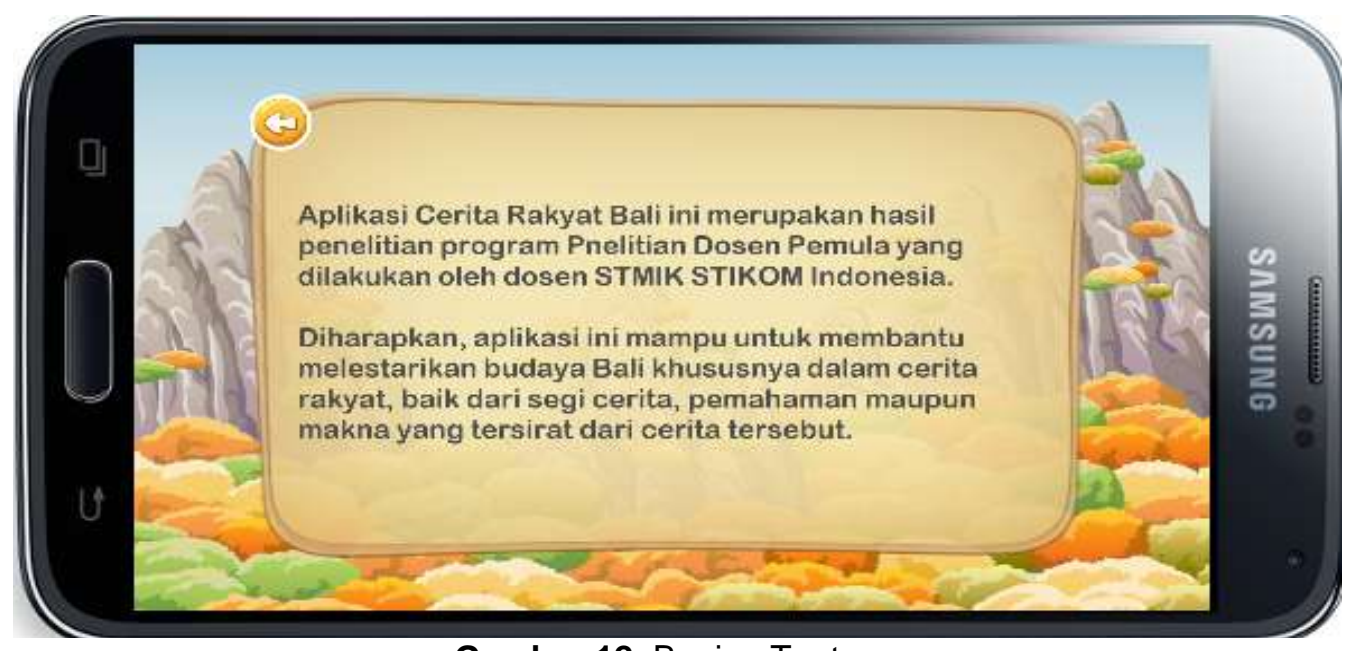

Gambar 12. Bagian Tentang 


\subsection{Hasil Analisa dan Pembahasan}

Pengujian dari aplikasi Games Cerita Rakyat Bali yang menggunakan Black-Box testing untuk melihat fungsionalitas dan metode survey untuk melihat respon dari pengguna.

\subsubsection{Black-box testing}

Pengujian aplikasi menggunakan tiga perangkat seluler yaitu Xiaomi Redmi 2 versi android 4.4.4, Samsung J2 dengan versi android 5.1.1, dan Asus Zenfone 2 Laser dengan versi android 6.0.1. Pengujian dilakukan untuk mengetahui apakah funsionalitas secara umum dari aplikasi sudah berjalan sesuai yang direncanakan. Tabel 1 menunjukkan hasil Black-box testing secara umum telah sesuai dengan hasil yang diharapkan.

Tabel 1. Hasil Black-box testing fungsionalitas aplikasi secara umum

\begin{tabular}{|c|c|c|c|}
\hline $\begin{array}{c}\text { Nama } \\
\text { Pengujian }\end{array}$ & $\begin{array}{c}\text { Bentuk } \\
\text { Pengujian }\end{array}$ & Hasil Yang Diharapkan & Hasil \\
\hline $\begin{array}{l}\text { Pengujian } \\
\text { tampilan } \\
\text { utama }\end{array}$ & $\begin{array}{l}\text { Membuka } \\
\text { aplikasi }\end{array}$ & $\begin{array}{l}\text { Tampilan muncul dengan } \\
\text { musik latar belakang }\end{array}$ & Berhasil \\
\hline $\begin{array}{l}\text { Pengujian } \\
\text { tombol cerita } \\
\text { rakyat }\end{array}$ & $\begin{array}{l}\text { Menekan } \\
\text { tombol cerita } \\
\text { rakyat }\end{array}$ & $\begin{array}{l}\text { Masuk ke bagian memilih } \\
\text { cerita }\end{array}$ & Berhasil \\
\hline $\begin{array}{l}\text { Pengujian } \\
\text { tombol } \\
\text { bantuan }\end{array}$ & $\begin{array}{c}\text { Menekan } \\
\text { tombol bantuan }\end{array}$ & Masuk ke bagian bantuan & Berhasil \\
\hline $\begin{array}{l}\text { Pengujian } \\
\text { tombol } \\
\text { setting }\end{array}$ & $\begin{array}{l}\text { Menekan } \\
\text { tombol setting }\end{array}$ & Masuk ke bagian setting & Berhasil \\
\hline $\begin{array}{l}\text { Pengujian } \\
\text { tombol } \\
\text { tentang }\end{array}$ & $\begin{array}{l}\text { Menekan } \\
\text { tombol tentang }\end{array}$ & Masuk ke bagian tentang & Berhasil \\
\hline $\begin{array}{l}\text { Pengujian } \\
\text { Tombol } \\
\text { memilih } \\
\text { Cerita }\end{array}$ & $\begin{array}{l}\text { Menekan salah } \\
\text { satu cerita } \\
\text { rakyat }\end{array}$ & $\begin{array}{c}\text { Masuk ke bagian cerita } \\
\text { sesuai dengan cerita rakyat } \\
\text { yang dipilih }\end{array}$ & Berhasil \\
\hline $\begin{array}{l}\text { Pengujian } \\
\text { Tombol } \\
\text { fungsional } \\
\text { pada bagian } \\
\text { cerita }\end{array}$ & $\begin{array}{c}\text { Menekan } \\
\text { tombol } \\
\text { fungsional yang } \\
\text { ada pada } \\
\text { bagian cerita }\end{array}$ & $\begin{array}{l}\text { Tombol berfungsi sesuai } \\
\text { dengan fungsinya }\end{array}$ & Berhasil \\
\hline $\begin{array}{l}\text { Pengujian } \\
\text { pergerakan } \\
\text { karakter } \\
\text { pada game }\end{array}$ & $\begin{array}{l}\text { Menekan pada } \\
\text { layar untuk } \\
\text { melakukan } \\
\text { pergerakan } \\
\text { karakter }\end{array}$ & $\begin{array}{l}\text { Karakter game bergerak } \\
\text { sesuai dengan penekanan } \\
\text { yang dilakukan dan skor } \\
\text { bertambah }\end{array}$ & Berhasil \\
\hline
\end{tabular}




\subsubsection{Metode Survey}

Metode survey digunakan untuk pengambilan data yang akan digunakan menganalisa aplikasi Game Cerita Rakyat Bali yang dikembangkan. Kuesioner dibagikan kepada 30 orang anak sampel secara acak dengan rentang usia 6-12 tahun yang memainkan aplikasi Game Cerita Rakyat Bali yang dikembangkan. Kritera yang digunakan adalah sangat baik, baik, cukup, kurang baik dan tidak baik. Terdapat tiga aspek yang digunakan yaitu aspek media, aspek hiburan dan aspek isi.

Aspek media yang digunakan dalam aplikasi Games Cerita Rakyat Bali meliputi.

1. Visual (layout, desain, warna)

2. Audio (musik dan suara)

3. Animasi

Tabel 2 menampilkan hasil penilaian 30 orang anak usia 6-12 tahun yang diambil secara acak didapat penilaian aspek media adalah Baik. Jumlah nilai berkriteria baik yang diberikan oleh responden adalah 49 . Jumlah nilai untuk kriteria sangat baik adalah 32 dan kriteria cukup adalah 9

Tabel 2. Jumlah Nilai Berdasarkan Aspek Media (visual, audio, animasi)

\begin{tabular}{cc}
\hline Kriteria & Jumlah Nilai \\
\hline Sangat Baik & 32 \\
Baik & 49 \\
Cukup & 9 \\
Kurang Baik & 0 \\
Tidak Baik & 0 \\
\hline TOTAL & 90
\end{tabular}

Aspek hiburan yang ada dalam aplikasi Games Cerita Rakyat Bali meliputi.

1. Tingkat kesulitan dalam memainkan game untuk anak usia 6-12 tahun.

2. Tingkat menyenangkan dalam memainkan game.

Tabel 3 menampilkan hasil penilaian 30 orang anak usia 6-12 tahun yang diambil secara acak didapat penilaian aspek hiburan adalah Baik. Jumlah nilai berkriteria baik yang diberikan oleh responden adalah 36 . Jumlah nilai untuk kriteria sangat baik adalah 18 dan kriteria cukup adalah 6 .

Tabel 3. Jumlah Nilai Berdasarkan Aspek Hiburan

\begin{tabular}{cc}
\hline Kriteria & Jumlah Nilai \\
\hline Sangat Baik & 18 \\
Baik & 36 \\
Cukup & 6 \\
Kurang Baik & 0 \\
Tidak Baik & 0 \\
\hline TOTAL & $\mathbf{6 0}$ \\
\hline
\end{tabular}

Aspek isi yang ada dalam aplikasi Games Cerita Rakyat Bali meliputi.

1. Pengetahuan tentang cerita crukcuk kuning, i kekua dan i lacur.

2. Pengetahuan tentang pesan moral yang terdapat pada masing-masing cerita.

Tabel 4 menampilkan hasil penilaian 30 orang anak usia 6-12 tahun yang diambil secara acak didapat penilaian aspek isi adalah Baik. Jumlah nilai berkriteria baik yang diberikan oleh responden adalah 31. Jumlah nilai untuk kriteria sangat baik adalah 29. 
Tabel 4. Penilaian Responden Berdasarkan Aspek Isi

\begin{tabular}{cc}
\hline Kriteria & Jumlah Nilai \\
\hline Sangat Baik & 29 \\
Baik & 31 \\
Cukup & 0 \\
Kurang Baik & 0 \\
Tidak Baik & 0 \\
\hline TOTAL & $\mathbf{6 0}$
\end{tabular}

\section{Kesimpulan}

Aplikasi Game Cerita Rakyat Bali menggunakan cerita rakyat bali I Kekua yang mempunyai pesan moral tepat janji, Crukcuk Kuning yang mempunyai pesan moral kejujuran dan I Lacur yang mempunyai pesan moral suka menolong. Aplikasi Game Cerita Rakyat Bali dikembangkan berbasis sistem operasi Android dan diperuntukkan untuk anak usia 6 sampai 12 tahun. Berdasarkan pengujian Black-box testing pada perangkat seluler bersistem operasi android didapat funsionalitas umum aplikasi sudah berjalan sesuai dengan harapan dan penilaian menggunakan kuesioner didapat aplikasi Game Cerita Rakyat Bali berkategori baik.

\section{Daftar Pustaka}

[1] Rahmawati, "Cerita Rakyat Makassar Sebagai Media Pembentukan Karakter," Jantra, vol. 10, no. 2, pp. 153-162, 2015.

[2] H. Insriani, "Cerita Rakyat Sebagai Media Pendidikan Karakter: Sebuah Upaya Pembacaan Reflektif," Jantra, vol. 10, no. 2, pp. 143-152, 2015.

[3] N. P. Parmini, "Eksistensi Cerita Rakyat dalam Pendidikan Karakter Siswa SD di Ubud," Jurnal Kajian Bali, vol. 5, no. 2, pp. 441-460, 2015.

[4] R. A. Santoso, D. Sunaryono, and I. Arieshanti, "Rancang Bangun Aplikasi Buku ' Dongeng ' - iOS," Jurnal Teknik Publikasi Online Mahasiswa ITS, vol. 2, no. 2, pp. 407412, 2013.

[5] M. K. Grady, H. Karnadi, and Y. H. Yulianto, "Perancangan Game Edukasi Cerita Rakyat Malin Kundang Untuk Anak," J. DKV Adiwarna, vol. 1, no. 4, p. 15, 2014.

[6] D. P. A. Sanjaya, I. K. A. Purnawan, and N. K. D. Rusjayanthi, "Pengenalan Tradisi Budaya Bali melalui Aplikasi Game Explore Bali Berbasis Android," Lontar Komputer: Jurnal IImiah Teknoogi Informasi, vol. 7, no. 3, pp. 162-173, 2016.

[7] S. Gusnetti and R. Isnanda, "Struktur dan Nilai-Nilai Pendidikan Dalam Cerita Rakyat Kabupaten Tanah Datar Provinsi Sumatera Barat," Jurnal gramatika, vol. 2, no. 1, pp. 128-140, 2016.

[8] G. G. P.S, "Platform Comparison Between Games Console, Mobile Games And PC Games," SISFORMA, vol. 2, no. 1. pp. 23-26, 2015. 